\title{
ARTICLES
}

\section{A STUDY TO EVALUATE THE EFFECTIVENESS OF STRUCTURED TEACHING PROGRAMME (STP) ON KNOWLEDGE REGARDING WIFS PROGRAMME AMONG ADOLOSCENTS}

Mrs. Komala H. K.*

*Professor, Adichunchanagiri College of Nursing, District Mandya, Karnataka, India. DOI: http://doi.org/10.47211/idcij.2020.v07iws02.004

\section{ABSTRACT}

Introduction: Adolescence is a vulnerable period in the human life cycle for the development of nutritional anemia, which has been constantly neglected by public health programs and is at high risk of iron deficiency anaemia due to accelerated increase in requirements for iron, as well as the social norm of early marriage and adolescent pregnancy. During this stage the requirement of nutrition and micronutrients is relatively high

Objectives: 1 . To assess the pre-test level of knowledge regarding WIFS Programme among adolescents. 2. To assess the post-test level of knowledge regarding WIFS Programme among adolescents.3. To evaluate the effectiveness of structured teaching Programme on knowledge regarding WIFS Programme among adolescents.4. To find out the association between gain in knowledge scores with selected demographic variables.

Methodology: The Quasi-experimental study design was adopted for the study. The 60 samples were selected based on the randomisation. Pre tested, validated self-administered tool was used to collect the data.

Result: The results shows that in the pre-test majority of the adolescent school children (68.3\%) having poor knowledge on WIFS Programme, but in post-test majority of the adolescent school children (73.3\%) having average knowledge on WIFS Programme The paired't' test computed between pre and post-test knowledge score was statistically significant at 0.05 level of significance. The calculated' $t$ ' value 11.17 is greater than table value $\left(t_{(59)}\right)=1.96$. The result shows there is a significant association between the gain in knowledge scores of adolescent WIFS Programme among adolescents with selected demographic variables like age $\left(x^{2}{ }_{(2)}=8.28\right)$, $\operatorname{sex}\left(x^{2}{ }_{(1)}=8.13\right)$, education of father $\left(x^{2}{ }_{(1)}=4.34\right)$.

Interpretation and conclusion:_The results showed that the mean post test score higher than mean pre-test score. Thus it can be concluded that there is significant improvement in the knowledge of adolescents regarding WIFS Programme after the administration of structured teaching Programme.

Key Words: WIFS programme, adolescents, structured teaching programme.

\section{ABOUT AUTHOR:}

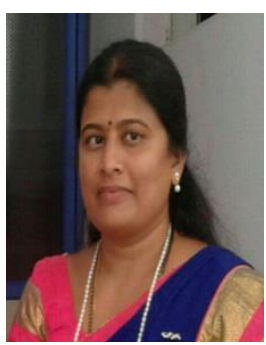

Author, Mrs. Komala H.K. is a professor in Adichunchanagiri College of Nursing, affiliated to Adichunchanagiri University in Mandya district, Karnataka, India. 


\section{INTRODUCTION}

Adolescent is a stage of transition from childhood to adulthood and is marked by the termination of childhood at one end and the beginning of adulthood at other end. According to WHO the adolescent period is from the age of 10-19 years. The beginning of adolescence is marked by profound physical and physiological changes including body growth, bone ossification, hormonal changes, development of secondary sexual characteristics etc ${ }^{1}$.

Worldwide more than 1.2 billion adolescents were present and make up 18 per cent of the world's population; more than half of all adolescents live in Asia. India is home to more adolescents of around 243 million than any other country followed by China around 201 million, East Asia around 122 million, South Asia around 90 million ${ }^{2}$.

In India, various studies conducted in different regions shows the prevalence of anaemia as follows : Madhya Pradesh 52.5\%,Gujarath 37\%,Uttar Pradesh 56.3\%,AndraPradesh 77.73\%,Tamil Nadu 58.4\%,Maharashtra $85.4 \%$,Shimla $21.5 \%$, Karnataka $41.5 \%$ respectively ${ }^{3}$.

The consequences of anaemia outlined above are compelling reasons for supporting programmes designed to reduce the prevalence and severity of anaemia. Recent global consensus agrees that in developing countries the provision of weekly iron and folic acid supplements for the control of anaemia in women should be viewed as one of the most important nutrition interventions and that critical elements of these programmes must be identified to ensure their successful implementation to improve the iron status of women and reduce the prevalence of anaemia ${ }^{4}$.

Treatment of anaemia in adolescents is mainly includes counselling them for correction of anaemia through iron rich diets, prescribing iron supplementation. It requires a multipronged approach to fight this multi factorial disorder. Adolescence is the best time to intervene not only because of growth and development but also because we can catch them easily through school health program involvement and get good results. Strategic focus is very important to prevent IDA from the point of view of productivity. ${ }^{5}$

The Ministry of Health and Family Welfare, Government of India has launched the Weekly Iron and Folic Acid Supplementation (WIFS) Programme in 2012 to reduce the prevalence and severity of nutritional anaemia in adolescent population (10-19 years) and this programme will be implemented in government and government aided schools from 6th to 12th standard in rural and urban areas. Under this programme for adolescents, IFA supplements are to be distributed free of cost on a weekly basis to the target groups, each IFA tablet containing $100 \mathrm{mg}$ elemental iron and $500 \mu \mathrm{g}$ folic acid for 52 weeks in a year. In addition to this Albendazole tablets for de-worming are to be administered twice a year to the same target groups ${ }^{6}$.

Investigator observed that many students were refused to take IFA tablets because they believed that it has got many side effects and also there were incidences of absentees due to IFA tablet administration. Based on the review of literature available, current data, expert's opinion the investigator felt there is a strong need to assess the knowledge of the adolescent students regarding WIFS programme in order to reduce the prevalence of anaemia among adolescent boys and girls.

\section{STATEMENT OF THE PROBLEM}

A Study to Evaluate the Effectiveness of Structured Teaching Programme (STP) on Knowledge Regarding WIFS Programme Among Adolescents.

\section{OBJECTIVES}

1. To assess the pre-test level of knowledge regarding WIFS programme among adolescents.

2. To assess the post-test level of knowledge regarding WIFS programme among adolescents.

3. To evaluate the effectiveness of structured teaching programme on knowledge regarding WIFS programme among adolescents.

\section{METHODS AND MATERIALS}

\section{Hypothesis}

H1: There will be a significant difference in mean pre-test and post-test level of knowledge regarding WIFS programme among adolescents. 


\section{ARTICLES}

H2: There will be a significant association between the gains in knowledge scores of adolescents with selected demographic variables.

\section{Research approach}

An evaluative approach was adopted to accomplish the objectives of the study.

\section{Research design}

Quasi experimental study

Conceptual frame work

Based on Daniel Stuffle Beams program evaluation model (CIPP Model)

\section{Population}

In this study population consist of adolescents.

\section{Sample}

Sample selected for this study adolescents in selected schools.

\section{Sample size}

A total of 60 adolescents.

\section{Sampling technique}

In this study simple random sampling by using lottery method.

Independent variables

Structured teaching programme.

Dependent variables

Knowledge on WIFS programme

\section{Method of data collection}

The permission was obtained from concerned authority. The investigator established good rapport with samples. Oral consent from each participant was obtained after collecting background data and pre-test was conducted on knowledge on WIFS programme. The structured teaching programme was given soon after the pre-test. The post test was done on $7^{\text {th }}$ day of structured teaching programme to the adolescents.

\section{Tool used for the study}

The investigation developed the tool as follows

\section{Section I}

It comprised of 10 items seeking information on demographic data such as age, sex, studying in, education of father, education of mother, family monthly income, diet pattern, living area, knowledge on WIFS programme, previous history of anaemia.

\section{Section II}

It consisted of 27 structured questionnaire on WIFS programme. Each item has one correct response and each item carries score of one. The maximum possible score was 27 and minimum possible score was 0 .

\section{Plan for data analysis}

- Demographic proforma was analyzed in terms of frequency and percentage.

- The knowledge score was analyzed by using frequency, percentage, mean, and mean percentage and standard deviation.

- Effectiveness of structured teaching programme was analyzed by using paired ' $t$ 'test.

- Association between gains in knowledge scores with selected demographic variables was calculated by using chi- square test.

\section{RESULTS}

Analysis of the study finding are categorized and presented under the following headings:

Section I: Description of the demographic variables of higher primary school children under study (table 1).

Section II: Distribution of samples according to their level of knowledge scores of the higher primary schoolchildren. (Table 2)

Section I11: Data on effectiveness of structured teaching programme (table 3 \& 4)

Section 1V: Association between gain in knowledge score with selected demographic variables. (Table 5) 
Table 1: Frequency and percentage distribution of higher primary school children according to demographic characteristics.

$\mathrm{N}=60$

\begin{tabular}{|c|c|c|c|c|}
\hline \multirow{2}{*}{$\begin{array}{l}\text { Sl. } \\
\text { No. }\end{array}$} & \multicolumn{2}{|c|}{ Demographic variables } & \multicolumn{2}{|c|}{ Adolescents } \\
\hline & Characteristics & Category & Frequency & Percentage(\%) \\
\hline \multirow{3}{*}{1} & \multirow{3}{*}{ Age } & a. $12-13$ years & 5 & 8.3 \\
\hline & & b. 14-15years & 45 & 75 \\
\hline & & c. 16 years \&Above & 10 & 16.7 \\
\hline \multirow{2}{*}{2} & \multirow[t]{2}{*}{ Gender } & a. Female & 23 & 38.3 \\
\hline & & b. Male & 37 & 61.7 \\
\hline \multirow{3}{*}{3} & \multirow{3}{*}{ Educational status } & a. 8th standard & 21 & 35 \\
\hline & & b. 9th standard & 20 & 33.3 \\
\hline & & c. 10 th standard & 19 & 31.7 \\
\hline \multirow{2}{*}{4} & \multirow{2}{*}{ Education of father } & a. No formal education & 42 & 70 \\
\hline & & b. $10^{\text {th }}$ standard & 18 & 30 \\
\hline \multirow[b]{2}{*}{5} & \multirow{2}{*}{ Education of mother } & a. No formal education & 46 & 76.7 \\
\hline & & b. $10^{\text {th }}$ standard & 14 & 23.3 \\
\hline \multirow{2}{*}{6} & \multirow{2}{*}{ Family monthly income } & a. $3000-5000 r s$ & 47 & 78.3 \\
\hline & & b. 5001-7000rs & 13 & 21.7 \\
\hline \multirow{2}{*}{7} & \multirow{2}{*}{ Type of diet } & a. Vegetarian & 22 & 36.7 \\
\hline & & b. Mixed diet & 38 & 63.3 \\
\hline \multirow{2}{*}{8} & \multirow[t]{2}{*}{ Area of Living } & a. rural & 39 & 65 \\
\hline & & b. urban & 21 & 35 \\
\hline \multirow{2}{*}{9} & \multirow{2}{*}{ Knowledge on WIFS } & a.Yes & 1 & 1.7 \\
\hline & & b. No & 59 & 98.3 \\
\hline \multirow{2}{*}{10} & \multirow{2}{*}{ If Yes } & a. mass media & 0 & 0 \\
\hline & & b. health worker & 1 & 1.7 \\
\hline \multirow{2}{*}{11} & \multirow{2}{*}{ Previous history of anaemia } & a. Yes & 1 & 1.7 \\
\hline & & b. No & 59 & 98.3 \\
\hline
\end{tabular}

Table 2: Frequency and percentage distribution of pre-test and post-test level of knowledge of higher primary school children

$\mathrm{N}=60$

\begin{tabular}{|c|c|c|c|c|}
\hline \multirow{2}{*}{ Level of knowledge } & \multicolumn{2}{|c|}{ Pre -test level of knowledge } & \multicolumn{2}{c|}{ Post-test level of knowledge } \\
\cline { 2 - 5 } & Frequency(f) & Percentage (\%) & Frequency(f) & Percentage (\%) \\
\hline Poor & 41 & 68.3 & 3 & 73.3 \\
\hline Average & 19 & 31.7 & 44 & 21.7 \\
\hline
\end{tabular}


Table 3: Overall mean, standard deviation (SD), mean percentage, paired $t$ value between pre-test and posttest $\mathrm{N}=60$

\begin{tabular}{|c|c|c|c|c|c|}
\hline Aspects & \multicolumn{2}{|c|}{ Adolescents of school children } & $\begin{array}{c}\text { Significant difference in } \\
\text { level of knowledge }\end{array}$ & $\begin{array}{c}\text { paired } t- \\
\text { test }\end{array}$ \\
\cline { 2 - 4 } & Mean & SD & Mean \% & & \\
\hline Pre test & 7.57 & 4.19 & 28.03 & & $\mathrm{t}=11.17$ \\
\hline Post test & 14.75 & 4.25 & 54.62 & & \\
& & & & & \\
\hline
\end{tabular}

$t_{(59)}=1.96 \quad$ highly significant at $p \leq 0.05$

Table 4: Association between gain in knowledge score and demographic variables

\begin{tabular}{|c|c|c|c|c|c|c|c|}
\hline & & & & & & $=60$ & \\
\hline Demogr & phic variables & Level of kr & dge gain & sample & df & Table & Chi square \\
\hline & & $\begin{array}{c}\text { Below } \\
\text { median( } \leq 7)\end{array}$ & $\begin{array}{c}\text { Above } \\
\text { median( } \leq 7)\end{array}$ & & & value & \\
\hline $\begin{array}{l}\text { Age } \\
\text { (years) }\end{array}$ & $\begin{array}{l}\text { a.12-13 } \\
\text { b.14-15 } \\
\text { c.16\&above }\end{array}$ & $\begin{array}{c}4 \\
23 \\
1\end{array}$ & $\begin{array}{c}1 \\
22 \\
9\end{array}$ & $\begin{array}{c}5 \\
45 \\
10\end{array}$ & 2 & 5.99 & $\begin{array}{c}x^{2}=8.28 \\
(S)\end{array}$ \\
\hline Sex & $\begin{array}{l}\text { a. Male } \\
\text { b. Female }\end{array}$ & $\begin{array}{c}5 \\
22\end{array}$ & $\begin{array}{l}18 \\
15\end{array}$ & $\begin{array}{l}23 \\
37\end{array}$ & 1 & 3.84 & $x^{2}=8.13 \quad(S)$ \\
\hline $\begin{array}{l}\text { Educational } \\
\text { status }\end{array}$ & $\begin{array}{l}\text { a. } 8^{\text {th }} \text { standard } \\
\text { b. } 9^{\text {th }} \text { standard } \\
\text { c. } 10^{\text {th }} \text { standard }\end{array}$ & $\begin{array}{c}11 \\
14 \\
7\end{array}$ & $\begin{array}{c}10 \\
6 \\
12\end{array}$ & $\begin{array}{l}21 \\
20 \\
19\end{array}$ & 2 & 5.99 & $\begin{array}{c}x^{2}=4.305 \\
\text { (NS) }\end{array}$ \\
\hline $\begin{array}{l}\text { Education of } \\
\text { father }\end{array}$ & $\begin{array}{l}\text { a. No formal } \\
\text { education } \\
\text { b. } 10^{\text {th }} \text { standard }\end{array}$ & $\begin{array}{c}24 \\
4\end{array}$ & $\begin{array}{l}18 \\
13\end{array}$ & $\begin{array}{l}42 \\
18\end{array}$ & 1 & 3.84 & $x^{2}=4.34(S)$ \\
\hline $\begin{array}{l}\text { Education of } \\
\text { mother }\end{array}$ & $\begin{array}{l}\text { a No formal } \\
\text { education } \\
\text { b. } 10^{\text {th }} \text { standard }\end{array}$ & $\begin{array}{c}21 \\
8\end{array}$ & $\begin{array}{c}25 \\
6\end{array}$ & $\begin{array}{l}46 \\
14\end{array}$ & 1 & 3.84 & $x^{2}=0.15$ (NS) \\
\hline $\begin{array}{l}\text { Family } \\
\text { monthly } \\
\text { income }\end{array}$ & $\begin{array}{l}\text { a. } 3000-5000 \text { rs } \\
\text { b. } 5001-7000 \text { rs }\end{array}$ & $\begin{array}{c}25 \\
7\end{array}$ & $\begin{array}{c}22 \\
6\end{array}$ & $\begin{array}{l}47 \\
13\end{array}$ & 1 & 3.84 & $\begin{array}{c}x^{2}=0.0017 \\
\text { (NS) }\end{array}$ \\
\hline Type of diet & $\begin{array}{l}\text { a. Vegetarian } \\
\text { b. Mixed diet }\end{array}$ & $\begin{array}{l}10 \\
23\end{array}$ & $\begin{array}{l}12 \\
15\end{array}$ & $\begin{array}{l}22 \\
38\end{array}$ & 1 & 3.84 & $x^{2}=1.26(\mathrm{NS})$ \\
\hline Area of Living & $\begin{array}{l}\text { a. rural } \\
\text { b. urban }\end{array}$ & $\begin{array}{l}20 \\
11\end{array}$ & $\begin{array}{l}19 \\
10\end{array}$ & $\begin{array}{l}39 \\
21\end{array}$ & 1 & 3.84 & $\begin{array}{c}x^{2}=0.0063 \\
\text { (NS) }\end{array}$ \\
\hline
\end{tabular}

$\mathrm{S}=$ Significant NS=Not Significant

\section{DISCUSSION}

The findings of the study indicated that structured teaching programme was effective in increasing the knowledge of adolescents regarding WIFS programme. 


\section{REFERENCES}

1. K. K. Gulani. Community health nursing (principles \& practices). $2^{\text {nd }}$ edition. Delhi: kumar publishing house; 2013.P.461-62.

2. UNICEF.Progress for Children (A report card on adolescents). $10^{\text {th }}$ edition. April 2012.p.8.

3. Bindra V. Anemia in Adolescence. World J Anemia2017; 1(1):18-19.p -19.

4. .MOHFW. Operational frame work, WIFS. Online (cited on 27 February 2018) available from http://tripuranrhm.gov.in/Guidlines/WIFS.pdf.

5. Koushik N.K, Bollu M, Ramarao NV,Nirojini PS,Nadendla RR .Prevalence of anaemia among the adolescent girls: a three months cross-sectional study.women2014;14(16):p12

6. National Family Health Survey-4. MOHFW. Govt of India. 